\title{
EMPATHY OF THE BANCASSURANCE CHANNEL: AN EMPIRICAL STUDY
}

\author{
Dr. Mousumi Choudhury \\ Assistant Professor \\ Department of Business Administration \\ University of Science and Technology \\ Meghalaya-793101, India \\ E-mail: mousumichoudhury6@gmail.com \\ Dr. Ranjit Singh \\ Associate Professor \\ Department of Management Studies \\ Indian Institute of Information Technology, Allahabad \\ Prayagraj-211015, Uttar Pradesh, India \\ E-mail: ranjitsingh@iiita.ac.in \\ Ms. K. Kajol \\ Research Scholar \\ Department of Management Studies \\ Indian Institute of Information Technology, Allahabad \\ Prayagraj-211015, Uttar Pradesh, India \\ E-mail: rsm2018003@iiita.ac.in \\ Dr. Shashi Kant Rai \\ Assistant Professor \\ Department of Management Studies \\ Indian Institute of Information Technology, Allahabad \\ Prayagraj-211015, Uttar Pradesh, India \\ E-mail: shashikant@iiita.ac.in
}

\begin{abstract}
Purpose: The purpose of the study is to assess the customers' perception regarding empathy exhibited by the bancassurance channel and factors affecting it.

Design/Methodology/Approach: Using random sampling, the data was collected from customers of several branches of State bank of India in Guwahati city of Assam, who have availed life insurance services from these branches. Tool of structured questionnaire was used to collect primary data. Mean, standard deviation, regression analysis was used to analyze the data and draw logical conclusions.
\end{abstract}


Findings: The study shows that customer perceives bancassurance channel to have a high level of empathy towards customers. It was also found that none of the demographic variables considered in the study have any impact on influencing perception. Therefore, policymaker can adopt one fits all approach in the case of demographic aspects to improve the empathetic nature showed by the bancassurance channel.

Research Limitations: The study takes into consideration the customers who have bought Life insurance service from various branches of State Bank of India, Guwahati, Assam, India.

Originality: The study is first of its kind in assessing customer's perception of empathy shown by the bancassurance channel. The study will be useful for researchers, academicians and those working in the area of bancassurance and in their understanding about factors influencing customer experience, satisfaction and retention strategy.

Major Conclusion: The study finds that customers of the bancassurance channel perceive that the channel demonstrates high empathy. Therefore, policymaker can advocate for an increase in penetration of life insurance through the bancassurance channel. As there is no association between the demographic factors and customers' perception towards empathy shown by the bancassurance channel, policymaker can adopt one fits all approach in the case of demographic aspects to improve the empathetic nature showed by the bancassurance channel.

Keywords: Bancassurance, Bank, Empathy, Employees, Insurance.

\section{INTRODUCTION}

Bancassurance is a business model to sell insurance products to bank's customers through banks branch network (Sharma et al., 2012; Aggrawal, 2004; Malik, 2014; Neelamega \& Veni, 2009; Viswanadham, 2005; Venugopal, 2011). Of late, globalization, liberalization, and technological advances have turned customers demanding, thus raising the concept of consumerism and there is a very high probability for customers to switch to the competitors' product if the desired level of satisfaction is not achieved. Banks are also not an exception to this and therefore, they are leaving no stone unturned to retain their customers (Aksoy, 2013; Giovanis \& Athanasopoulou, 2018; Tsoukatos \& Rand, 2006; Vera \& Trujillo, 2017; Wieseke et al., 2012). It is found that the key to a successful business is satisfied customers (Kristensen et al., 1992; Zeithaml et al., 1996; McColl-Kennedy \& Scheider, 2000).

Parasuraman et al. (1988) have shown the significant impact of service quality on customer satisfaction. He identified five dimensions of service quality i.e., reliability, responsiveness, tangibility, assurance and empathy. Choudhury and Singh (2015a); Choudhury and Singh (2015b) and Choudhury and Singh (2016) have studied the measurement of reliability, responsiveness, and assurance dimension of bancassurance and its impact thereon, however, empathy and its measurement has not yet been exclusively dealt by any specific studies and thereof, in this study, this dimension is exclusively addressed. Among the SERVQUAL dimensions, empathy and security are significantly related to customer satisfaction in the banking industry (Islam \& Ali, 2011). Empathy impacts customer satisfaction (Bahia \& Nantel, 2000; Rijwani, et al., 2017; Zaim et al., 2013). Siddiqi (2011) found that empathy had the highest positive correlation with customer satisfaction. 
Empathy is defined as “a person's ability to sense another's thoughts feelings, and experiences, to share other's emotional experience, and to react to the observed experiences of another person" (Wieseke et al., 2012; Davis 1996; Rogers 1959; Duan \& Hill 1996; Moore, 1990; Redmond, 1989). Several researchers highlighted the importance of the empathy dimension in respect of establishing better customer employee communication (Markovic et al., 2015; Solomon et al., 1985; Surprenant \& Solomon, 1987). Empathic workers completely comprehend their clients' needs and are subsequently ready to tailor their interactive behavior to a particular client (Giacobbe et al., 2006; Pettijohn et al., 2011; Weitz, 1978; Gremler \& Gwinner, 2008). Coan (1984) inferred that empathy is a switching barrier for customers (DeWitt \& Brady 2003). Empathy is an essential requirement for providing successfully the desired services (Parasuraman et al., 1988; Zeithaml et al., 1996; Gabbott \& Hogg 2001).

The empathy of employees has a significant impact on customer satisfaction (Markovic et al., 2015; Wieseke et al., 2012, Daniels, et al., 2014; Meneses \& Larkin, 2012). In the case of the banking business, a significant number of communications between employees and customers took place to complete various procedures (Chakrabarty, et al., 2012; Lee, et al., 2011). The empathy shown by an employee to customer contributes positively to satisfaction of customer (Gorry \& Westbrook, 2011; Lee et al., 2011; Homburg et al., 2009; Boorom et al., 1998; Comer \& Drollinger 1999; Drollinger et al., 2006; Pilling \& Eroglu, 1994). The combined effect of all these is free word-of-mouth publicity by the customers and repurchase of the same brand by the same customers (Barnes et al., 2016; Barnes et al., 2015; Nyadzayo \& Khajehzadeh, 2016). However, lacks of empathy can damage customers' perception of the service quality of a brand (Abbasi \&Alvi, 2013; Agnihotri \& Krush, 2015). Demographic factors also affect the customers' perception regarding empathy of the bancassurance channel but with a varying degree (Choudhury \& Singh, 2018).

Therefore, the policymakers of bancassurance channels need to identify the factors that positively influence customer's perception regarding empathy shown by employees. This will help the bancassurance channel in generating a competitive advantage over its competitors. This would further help a bank in designing a framework that will contribute to form a positive perception of customers regarding empathy shown by the bancassurance channel. Banks earn significant non-interest income through the bancassurance channel. This makes the bancassurance channel a profitable business model for banks (Leepsa \& Singh, 2016; Leepsa \& Singh, 2017). Thus, it becomes vital to know the customer's perception towards employees' empathic manner in the bancassurance channel as it elevates the level of satisfaction among customers (Weitz, 1981).

Hence a study on measuring customer's perception regarding empathy shown by bancassurance channel is important to reveal the customers' perception regarding the empathetic nature of employees of bancassurance channel and for policy recommendation. The key objectives of the study are:

i. To assess customers' perception regarding empathy shown by the bancassurance channel;

ii. To study the impact of demographic factors on customers' perception regarding empathy in the bancassurance channel.

Key measurable questions that address these objectives are as follows:

a. What is the perception of customers towards the empathy shown by the bancassurance channel? 
b. Is there any impact of demographic variables on customers' perception towards empathy shown by the bancassurance channel?

The rest of the paper is ordered as follows: Section 2 presents a review of related studies, section 3 consists of data and methodology, section 4 describes the analysis and findings, section 5 presents the conclusion and policy implications of the study.

\section{REVIEW OF RELATED STUDIES}

There have been many studies documenting the importance of empathy and its measurement in several industries.

Empathy leads to the continuous use of banking services by its customers (Van Iwaarden et al., 2003; Lo et al., 2010; Nupur 2010; Santhiyavalli, 2011; Shanka, 2012; Devi \& Ramburuth, 2012). Ilyas (2013) and Rajalakshmi (2016) found that empathy is one of the most significant factors considered by customers while assessing service quality. Empathy helps in bringing customer satisfaction (Lau et al., 2013; Hamzah et al., 2017). Customers have a favorable perception regarding the bancassurance channel (Singh \& Choudhury, 2017).

Barot et al. (2012) found that an insurance company wins customers based on empathy, responsiveness, and corporate image. Empathy has a role in influencing the customer perception in respect of service quality in the life insurance industry (Singh et al., 2014). Empathic services with the help of tangibles lead to and improve customers' satisfaction (Jothi, 2016). Anandhi (2016) found that the most important service quality dimension in respect of life insurance companies is reliability and empathy dimension.

Empathy helps in building positive emotions toward the brand (Lee et al., 2011). Employee's ability to understand customer emotions, expectations, and responding accordingly in the coordination with appropriate interactive behaviors increases loyalty towards the brand (Jones \& Shandiz, 2015). Empathic employees have the ability to provide personalized assistance to customers (Wieseke et al., 2012) resulting in higher customer satisfaction. The empathetic employee develops a long-lasting relationship between customers and the brand (Agnihotri \& Krush, 2015; Itani \& Inyang, 2015).

Age is an influences customer perception of service quality (Homburg \& Giering, 2001; Siu \& Cheung, 2001; Kumbhar, 2011; Ganesan-Lim et al., 2008; Ahmad et al., 2010). However, Elangovan and Sabitha, (2011) and Ramez (2011) observed no such relationship between age and service quality perception. Min and Khoon (2013) found that male and female customers to be different in their perceptions about the dimensions of service quality. But there exist a few studies that report no significant influence of gender on service quality perceptions e.g., Ganesan-Lim et al. (2008); Kumari and Rani (2011) and Kumbhar (2011). Marital status is one important factor affecting the customers' perception regarding service quality (Sasikala, 2013). However, there exist a few studies that report no such relationship (Anand \& Selvaraj, 2012). Some studies also found income to be a significant influence of customer's perception of service quality (Siu \& Cheung 2001; Kumbhar, 2011). A few studies, however, have found no significant relationship between the income of customers and their perception regarding service quality (Elangovan \& Sabitha, 2011; Anand \& Selvaraj, 2012; Dewan \& Mahajan, 2014). The relationship of service quality perceptions with education level is indicated by studies such as Kumari and Rani (2011); Kumbhar (2011) and Min and Khoon (2013). A few studies, on the other hand, show no such relationship between educational level and service quality perception (Elangovan \& Sabitha, 2011; Anand \& Selvaraj, 2012; Dewan \& Mahajan, 2014). Safakli (2007) and Kumbhar (2011) found the occupation of customer have an impact on the service quality 
perceptions. In contrast, a few studies have found no such differences prevailing in customers' quality perceptions concerning for the occupation (Urban \& Pratt, 2000; Kumari \& Rani, 2011).

It is evident from the above discussion that several studies have been carried out on empathy displayed in the banks, insurance, and other industries. However, in respect of bancassurance no such study exists. Thus, there is a need to study the empathy exhibited in the context of bancassurance and its related aspects. Moreover, conducting this kind of study in the context of India is another important dimension because, in the Indian context, limited studies are conducted. This study is expected to fill all these gaps. Given the mixed findings of past studies regarding demographic profile's influence on customer perception of service quality, the present study attempts to study the impact of demographic variables on customers' perception towards empathy dimension of service quality in bancassurance channel.

\section{DATA AND RESEARCH METHODOLOGY}

The present study is a descriptive one. The 33,31,050 numbers of customers as of $31^{\text {st }}$ March 2019 availing life insurance services from the 37 branches of the State Bank of India, Guwahati, Assam constitute the population of the study. A sample of 345 customers was chosen using a simple random sampling method at a 95\% level of confidence and a 5\% confidence interval. A structured questionnaire specifically designed to measure the customers' perception regarding empathy shown by the employees of the bancassurance business channel was used to collect primary data. Four numbers of variables were identified which can be used to measure empathy towards the bancassurance channel. The Likert scale was framed using those variables. A score was given from 5 to 1 for each of the selected dimensions, where 5 denotes a very high level of empathy (strongly agree) and 1 indicates a very low level of empathy (strongly disagree).The variables identified through the literature review were 'Convenient working hours for customers', 'Working to gain customers confidence', 'individualized attention to customers', and 'assessing customers' actual need of insurance'. Demographic variables such as age, gender, marital status, number of family members, family income, education, and occupation were considered to examine the influence of demographic profile on customer's perception towards empathy shown in bancassurance channel.

The important statistical tools used in this study were mean, standard deviation; Cronbach's alpha, and multiple linear regression analysis.

\section{ANALYSIS AND FINDINGS}

The analysis and findings of the study are as follows:

\section{Measuring Perception of Customers in Respect of Empathy Shown by Bancassurance Channel}

The value of Cronbach's Alpha, a measure to assess the reliability of the questionnaire, was found to be 0.834 for a scale consisting of 4 items. This indicates that the scale used to measure empathy is reliable (Nunnaly, 1978) and the items are taken to measure the latent variable, i.e., empathy is measuring it.

The mean value and standard deviation of all the four variables considered to measure empathy of the employees in the bancassurance channel are considered and summarized in table 
Table 1. Item Statistics with respect to empathy

\begin{tabular}{|l|l|l|}
\hline Particulars & Mean & $\begin{array}{l}\text { Standard } \\
\text { Deviation }\end{array}$ \\
\hline Convenient working hours for customers & 3.89 & 0.444 \\
\hline Work to gain customers' confidence & 3.77 & 0.651 \\
\hline Individualized attention is given to customers & 3.59 & 0.672 \\
\hline Assessing customers actual requirement of insurance & 3.21 & 0.796 \\
\hline Overall Mean & 14.46 \\
\hline Overall standard deviation & 2.135 \\
\hline
\end{tabular}

Source: Compiled by authors from Questionnaire

Table 1 shows that customers perceive the bancassurance channel to be highly empathetic in respect to the factors such as 'convenient working hours for customers. It is relatively low in respect of the factor such as 'assessing the actual need for insurance of the customers.

The scale considered to measure empathy of employees working in the bancassurance channel contains 4 items. A score of 5,4,3,2 and 1 was given to the respondents for their responses of strongly agree, agree, moderately agree, disagree, and strongly disagree respectively. The maximum score a respondent can score in each of the items was 5 . Therefore, the maximum possible score was 20 (4X5). Similarly, the minimum score a respondent can score in each of the items was 1 . Therefore, the minimum possible score was 4 (4X1). The difference between the maximum and minimum possible score was 16 (20-4). To ascertain the degree of empathy at five levels, this range (16) was divided by 5 which come out to be 3.2 . Adding 3.2 with 4 (lowest possible score), the very low level of risk perception range (4-7.2) was obtained. Similarly, adding 3.2 with subsequent value, the next higher range was obtained. In table 2 , the empathy score is interpreted. Singh and Bhowal (2011) and Singh (2012) have framed a similar interpretation tables using the similar upper limit exclusive scale.

Table 2. Interpretation table to interpret the empathy score

\begin{tabular}{|l|l|}
\hline Perception score & Interpretation \\
\hline $4-7.2$ & Very low level of empathy \\
\hline $7.2-10.4$ & Low level of empathy \\
\hline $10.4-13.6$ & Moderate level of empathy \\
\hline $13.6-16.8$ & High level of empathy \\
\hline $16.8-20$ & Very high level of empathy \\
\hline
\end{tabular}

Source: Compiled by authors from Questionnaire

The overall mean value as per table 1 is 14.46 which falls under the interval of the high level of empathy as interpreted in table 2.It can, thus, be inferred that customers perceive bancassurance channel to have a high level of empathy in making available insurance- related services. This is in the alignment with a study conducted by Vikas (2011).

\section{Demographic Profile of Customers and Its Impact on Their Perception Regarding Empathy Shown by Bancassurance Channel}


To measure the effect of the demographic profile of customers on their perception towards empathy shown by the bancassurance channel, multiple linear regressions were performed the result of which is summarized in tables 3 and 4.

Table 3. Model Summary

\begin{tabular}{|l|l|l|l|l|}
\hline Model & $\mathrm{R}$ & $\begin{array}{l}\mathrm{R} \\
\text { Square }\end{array}$ & Adjusted R Square & $\begin{array}{l}\text { The Std. Error of the } \\
\text { Estimate }\end{array}$ \\
\hline 1 & $0.159(\mathrm{a})$ & 0.025 & 0.005 & 0.66722 \\
\hline
\end{tabular}

Source: Compiled by authors from Questionnaire

Table 3 demonstrates that only $2.5 \%$ of the variations in the customers' perception towards empathy demonstrated by the bancassurance channel of an insurance company is explained by the select demographic factors such as age, gender, marital status, number of family members, family income, education, and occupation.

Table 4. Coefficient

\begin{tabular}{|l|l|l|l|l|l|l|}
\hline Model & & Sum of Squares & $\mathrm{df}$ & $\begin{array}{l}\text { Mean } \\
\text { Square }\end{array}$ & F & Sig. \\
\hline \multirow{2}{*}{1} & Regression & 3.903 & 7 & 0.558 & 1.252 & $0.273(\mathrm{a})$ \\
\cline { 2 - 7 } & Residual & 150.027 & 337 & 0.445 & & \\
\cline { 2 - 7 } & Total & 153.930 & 344 & & & \\
\hline
\end{tabular}

Source: Compiled by authors from Questionnaire

Table 4 shows that the relationship between the demographic profile of customers and their perception towards the empathy exhibited by the bancassurance channel is not significant since the p-value of 0.273 is more than the threshold limit of 0.05 to get it accepted in the given statistical test. Since the value of R square is very low (.025) and, the p-value is more than 0.05, no significant association can be discerned between the demographic profile of the customers and their perception towards the empathy shown by the bancassurance channel.

\section{CONCLUSION AND POLICY IMPLICATIONS}

The study finds that customers of the bancassurance channel perceive that the channel demonstrates high empathy. This acts as an advantage for the bancassurance channel. The reason is that empathetic behavior shown by the bancassurance channel will eventually result in higher levels of customer satisfaction (Homburg et al., 2009). Therefore, policymaker can advocate for an increase in penetration of life insurance through the bancassurance channel. RBI in connotation with IRDA has already passed the guidelines for banks to be a broker of insurance services (RBI, 2015). This new regulation will allow each bank to tie up with up to three life insurance companies. This brokerage system, thus, will give more freedom of choice to the customer of the bank in availing insurance service from the bank. Since the customers perceive the bancassurance channel to be empathetic in providing insurance service, therefore, freedom of choice will make the customers more inclined and satisfied towards this channel. Life insurers in the rural markets have not done well (Vimala \& Alamelu, 2018). Rural people do not believe ininsurers (Siddiqui \& Das, 2017). As the bancassurance channel seems to have high empathy 
towards customers, therefore, bancassurance channel can be beneficial to tap the untapped rural market (Siddiqui \& Das, 2017).Bancassurance channel can be made compulsory for Rural Banks, Regional Banks, and other Small finance banks operating in rural areas because the rural market has tremendous potential, and thus, it can be a good model for bringing financial inclusion as well (Choudhury \& Singh, 2015c).

Empathic employees can fully understand the needs of their customers and can tailor the communication according to the interest and need of their customers (Giacobbe et al., 2006; Pettijohn et al., 2011; Weitz, 1978) which leads to successful service encounter (Boorom et al., 1998; Comer \& Drollinger, 1999; Drollinger, et al., 2006; Pilling \& Eroglu, 1994; Barot et al., 2012) and thereby customer satisfaction (Bahia \& Nantel, 2000; Rijwani et al., 2017; Zaimetal., 2013). Thus, the bancassurance channel should consider appropriate strategies to make the employees empathetic towards their customers. Employees can be trained to make capable of sensing the customer's expectations and emotions and sharing this emotion while interacting with customers (Schneider \& Schechter, 1991). Employees' abilities to sense customer expectation can be developed by Role Playing or Mystery shopping method which will give the employees scope to keep themselves in the place of customers and to better understand how the customers perceive the service encounters (Finn \& Kayande, 1999; Grove \& Fisk, 1992). An approach called "interaction routing" can also be implemented to make employees empathetic towards customers (Van Dolenet al., 2002). An empathetic approach among employees will also influence their emotional intelligence in the workplace (Goleman, 2005). Implementation of the IT-Governance framework can also be one such alternative (Singh et al., 2020).

Through bancassurance, life insurance policies can be sold to the customers of the bank who opened their bank account due to the initiative taken by the Government such as Pradhan Mantri Jan Dhan Yojana (PMJDY) in India, to bring financial inclusion among the people at the grass -root level. Buying a life insurance policy is yet not preferred by most of the people in India (Tagra \& Dhiman, 2016; Raju \& Murugeshwaran, 2017). Creating awareness about life insurance can help in bringing this desired change (Banne \& Bhola, 2014). Awareness empowers people (Bhattacharjee \& Singh, 2017; Roy et al., 2017; Singh \& Kar, 2011). Bancassurance being perceived as empathetic by customers can increase customer's awareness about a life insurance policy. This is because empathy is a key factor in positively impacting the dynamic exchange of information between the customer and a company (Parasuraman et al., 1985 and 1991). Higher levels of empathy yield stronger and more meaningful interpersonal relationships (Rychlak, 1973). Thus, the bancassurance channel can arrange awareness camps, communicate properly about the benefits of life insurance policy, and can educate people about the utilities of the life insurance policy.

The present study, however, does not identify any association between the chosen demographic factors and customers' perception towards empathy shown by the bancassurance channel. This indicates that to improve the empathetic nature of bancassurance as perceived by the customer, policymaker can adopt one fits all approach in case of demographic aspects (Singh \& Bhattacharjee, 2010a; Singh \& Bhattacharjee, 2010b; Deb \& Singh, 2017a, Deb \& Singh, 2017b).

Further studies can be conducted to identify the association between psychographic features of customers and their perception of empathy shown by bancassurance. A comparative study can also be conducted to find out the perception of customers regarding empathy shown by the bancassurance channel and the traditional channel of buying insurance so that tailor- made policies for the bancassurance channel can be framed to enhance empathy of the channel. 
Volume of insurance premium paid may also have an impact on the overall empathy shown by the bancassurance channel. Future study can be directed towards this as it was done by Singh and Bhowal (2009).

\section{REFERENCES}

Abbasi, A. S., \& Alvi, A. K. (2013). Impact of employee characteristics and their performance on customer satisfaction. Science International, 25(2), 387-394.

Aggarwal, V. (2004). Bancassurance Concept, Framework and Implementation. The Journal of Insurance Institute of India, 30(1), 34-51.

Agnihotri, R., \& Krush, M. T. (2015). Salesperson empathy, ethical behaviors, and sales performance: The moderating role of trust in one's manager. Journal of Personal Selling \& Sales Management, 35(2), 164-174. https://doi.org/10.1080/08853134.2015.1010541

Ahmad, A., Rehman, K., Saif, M. I., \& Safwan, M. N. (2010). An empirical investigation oflslamic banking in Pakistan based on perception of service quality. African Journal of Business Management, 4(6), 1185-1193.

Aksoy, L. (2013). How do you measure what you can't define? The current state of loyalty measurement and management. Journal of Service Management, 24(4), 356-381. https://doi.org/10.1108/josm-01-2013-0018

Anand, S. V., \& Selvaraj, M. (2012). Impact of demographic variables on consumer satisfaction in banking sector - An empirical study. International Journal of Scientific and Research Publications, 2(5), 1-7.

Anandhi, K. (2016). The Service Quality Gap Analysis - A Studyon Selected Life Insurance Companies in Madurai. International Journal of Management, 7(5), 106-115.

Bahia, K., \& Nantel, J. (2000). A reliable and valid measurement scale for the perceived service quality of banks. International Journal of Bank Marketing, 18(2), 84-91. https://doi.org/10.1108/02652320010322994

Banne, A. S., \& Bhola, S. S. (2014). Awareness of Life Insurance among Sample Customers. Indian Streams Research Journal, 4(7), 1-12.

Barnes, B. R., Leonidou, L. C., Siu, N. Y. M., \& Leonido, C. N. (2015). Interpersonal Factors as drivers of quality and performance in Western-Hong Kong inter organizational business relationships. Journal of International Marketing, 23, 23-49. https://doi.org/10.1509/jim.14.0008

Barnes, D. C., Collier, J. E., Howe, V., \& Douglas, H. K. (2016). Multiple paths to customer delight: The impact of effort, expertise and tangibles on joy and surprise. Journal of Services Marketing, 30(3), 277-289. https://doi.org/10.1108/jsm-05-2015-0172 
Barot, H., Patel, J., \& Patel, S. (2012). Service quality and customer satisfaction in Indian Insurance Industry. PRERANA Journal, 1-13.

Bhattacharjee, J., \& Singh, R. (2017). Awareness about equity investment among retail investors: A kaleidoscopic view. Qualitative Research in Financial Market, 9(4), 310324. https://doi.org/10.1108/qrfm-04-2017-0036

Boorom, M. L., Jerry R. G., \& Rosemary P. R. (1998). Relational Communication Traits and Their Effect on Adaptiveness and Sales Performance. Journal of the Academy of Marketing Science, 26(1), 16-30. https://doi.org/10.1177/0092070398261003

Chakrabarty, S., Brown, G., \& Widing, R. E. (2012). The role of top management in developing a customer-oriented sales force. Journal of Personal Selling \& Sales Management, 32(4), 437-450. https://doi.org/10.2753/pss0885-3134320403

Choudhury, M., \& Singh, R. (2018). Bancassurance Business in India. New Delhi:Notion press.

Choudhury, M., Singh, R., \& Saikia, H. (2016). Measuring customers' experience in bancassurance: An empirical study. Trziste, 28(1), 47-62.

Choudhury, M., \& Singh, R. (2015a). Customers' Perception regarding reliability of bancassurance channel: an empirical study.SIJ Transaction on Industrial, Financial and Business Management, 3(4), 41-48.https://doi.org/10.9756/sijifbm/v3i2/03040120102

Choudhury, M., \& Singh, R. (2015b). Perception of customers towards responsiveness of bancassurance channel: An empirical study in Assam. International Journal of Entrepreneurship \& Development Studies, 3(1), 19-35.

Choudhury, M., \& Singh, R. (2015c). Customers' Experience in Financial Inclusion through Bancassurance. The Journal of Insurance Institute of India, 2(4), 55-61.

Choudhury, M., Singh, R. (2016). Customers' Perception regarding assurance of Bancassurance channel. Acta Universitatis Sapientiae Economics and Business, 4, 85-10. https://doi.org/10.1515/auseb-2016-0005

Coan, G. Jr. (1984). Rapport: Definitions and Dimensions. Advances in Consumer Research, 11(1), 333-336.

Comer, L. B., \& Tanya, D. (1999). Active Empathetic Listening and Selling Success: A Conceptual Framework. Journal of Personal Selling and Sales Management, 19(1), 1529.

Daniels, K., Glover, J., \& Mellor, N. (2014). An experience sampling study of expressing affect, daily affective well-being, relationship quality, and perceived performance. Journal of Occupational and Organizational Psychology, 87(4), 781-805. https://doi.org/10.1111/joop.12074 
Davis, M. H. (1996). Empathy: A Social Psychological Approach. Boulder: Westview Press.

Deb, S., \& Singh, R. (2017a). Influence of Demographic and Socio-economic Variables on Investors' Risk Perception towards Mutual Fund: A Study on Bank Employees of Tripura.Bank Parikrama, XLII(1\& 2), $94-116$.

Deb, S., \& Singh, R. (2017b). Investment Behaviour towards Mutual Fund: Are Demographic Variables Really Significant? A Study on Bank Employees of Tripura.The IUP Journal of Bank Management, 16(1), 62-74.

Devi, R. V., \& Ramburuth, H. K. S. (2012). Assessing Service Quality in the Mauritian Banking Sector Using SERVQUAL. Prestige International Journal of Management \& ITSanchayan, 1(1), 115-126. https://doi.org/10.37922/pijmit.2012.v01i01.007

Dewan, M., \& Mahajan, S. (2014). Customer Satisfaction and the moderating effect of demographics in public sector banks. JOSR Journal of Business and Management, 3(2), 29-35. https://doi.org/10.9790/487x-16322935

DeWitt, T., \& Michael, K. B. (2003). Rethinking Service Recovery Strategies. Journal of Service Research, 6(2), 193-207. https://doi.org/10.1177/1094670503257048

Drollinger, T., Lucette B. C., \& Patricia, T. W. (2006). Development and Validation of the Active Empathetic Listening Scale, Psychology and Marketing, 23(2), 161-180. https://doi.org/10.1002/mar.20105

Duan, C., \& Clara, E. H. (1996). The Current State of Empathy Research. Journal of Counselling Psychology, 43(3), 261-274. https://doi.org/10.1037/0022-0167.43.3.261

Elangovan, R., \& Sabitha, K. (2011). Customers perception towards internet banking servicesA Study with reference to Puducherry territory.Sankhya-Internationaljournal al of Management and Technology, 2(2), 60-63.

Finn, A., \& Kayande, U. (1999). Unmasking a Phantom: A Psychometric Assessment of Mystery Shopping. Journal of Retailing, 75(2), 195-217.

Gabbott, M., \& Hogg, G. (2001). The Role of Non-Verbal Communication in Service Encounters: A Conceptual Framework, Journal of Marketing Management, 17(1-2),526. https://doi.org/10.1362/0267257012571401

Ganesan-Lim, C., Russell-Bennett, R., \& Dagger, T. (2008). The impact of service contact type and demographic characteristics on service quality perceptions. Journal of Services Marketing, 22(7), 43-57. https://doi.org/10.1108/08876040810909677

Giacobbe, R. W., Donald, W. J. Jr., Lawrence, A. C., \& Claudia M. B. (2006). A Contingency Approach to Adaptive Selling Behavior and Sales Performance: Selling Situations and 
Salesperson Characteristics. Journal of Personal Selling and Sales Management, 26(2), 115-142. https://doi.org/10.2753/pss0885-3134260202

Giovanis, A. N., \& Athanasopoulou, P. (2018). Consumer brand relationships and brand loyalty in technology mediated services. Journal of Retailing and Consumer Services, 40, 287294. https://doi.org/10.1016/j.jretconser.2017.03.003

Goleman, D. (2005). Emotional Intelligence: Why It Can Matter More Than IQ, New York, United States: Penguin Random House.

Gorry, G. A., \& Westbrook, R. A. (2011). Once more, with feeling: Empathy and technology in customer care. Business Horizons, 54(2), 125-134. https://doi.org/10.1016/j.bushor.2010.10.003

Gremler, D. D., \& Kevin P. G. (2008). Rapport-Building Behaviors Used by Retail Employees. Journal of Retailing, 84(3), 308-324. https://doi.org/10.1016/j.jretai.2008.07.001

Grove, S. J., \& Raymond, P. F. (1992). Observational Data Collection Methods for Services Marketing: An Overview. Journal of the Academy of Marketing Science, 20(3), 217-224. https://doi.org/10.1007/bf02723408

Hamzah, Z. L, Lee, S. P., \& Moghavvemi, S. (2017). Elucidating perceived overall service quality in retail banking. International Journal of Bank Marketing, 35(5), 781804. https://doi.org/10.1108/ijbm-12-2015-0204

Homburg, C., Wieseke, J., \& Torsten, B. (2009). Implementing the Marketing Concept at the Employee-Customer Interface: The Role of Customer Need Knowledge. Journal of Marketing, 73(4), 64-81. https://doi.org/10.1509/jmkg.73.4.64

Homburg. C., \& Giering. A. (200I). Personal characteristics as moderators of the relationship between customer satisfaction and loyalty: An empirical analysis .Psychology \&Marketing, 18(1),43-66.https://doi.org/10.1002/1520-6793(200101)18:1<43::aid$\operatorname{mar} 3>3.0 . \operatorname{co} ; 2-\mathrm{i}$

Ilyas, A., Nasir, H., Malik, M. R., Mirza, U., Munir, S., \& Sajid, A. (2013). Assessing the service quality of Bank using Servqual model. Interdisciplinary journal of contemporary research in business, 11(4), 390-400.

Islam, S., \& Ali, B. (2011). Measuring Service Quality of Banks: An Empirical Study. Research Journal of Finance and Accounting, 2(4), 74-85

Itani, O. S., \& Inyang, A. E. (2015). The effects of empathy and listening of salespeople on relationship quality in the retail banking industry. International Journal of Bank Marketing, 33(6), 692-716. https://doi.org/10.1108/ijbm-06-2014-0076 
Jones, J. L., \& Shandiz, M. (2015). Service quality expectations: Exploring the importance of SERVQUAL dimensions from different non-profit constituent groups. Journal of Nonprofit\& Public Sector Marketing, 48-69. https://doi.org/10.1080/10495142.2014.925762

Jothi, L. (2016). Service Quality and Customer Satisfaction in Life Insurance Business, Australian Journal of Basic and Applied Sciences, 10(1), 636-641.

Kristensen, K., Dahlgaard, J. J., \& Yuen T. C. (2013). Measuring Service Quality in the Banking Industry: A Hong Kong Based Study, Contemporary Management Research, 9(3), 263-282.https://doi.org/10.7903/cmr.11060

Kumari, H. V., \& Rani, S.S. (2011). Customer perception of service quality in the retail banking sector.European Journal of Business and Management, 3(3), 299-306.

Kumbhar. V. M. (2011). Customers' Demographic Profile and Satisfaction in E-Banking Services: A Study of Indian Banks. International Journal for Business, Strategy \& Management, 1(1), 1-9.

Lee, S., Comer, L. B., Dubinsky, A. J., Scbafer, K. (2011). The role of emotion in the relationship between customers and automobile sales people. Journal of Managerial Issues, 23(2), 206-226.

Leepsa, N. M., \& Singh, R. (2016). The impact of Acquisition of an insurance company on Bank's Financial Performance: A Study on the Acquisition of Metlife India Insurance co. Ltd by Punjab National Bank, The IUP Journal of Bank Management, 15(3), 52-67.

Leepsa, N. M., \& Singh, R. (2017). Contribution of Bancassurance on the Performance of Bank: A Case Study of Acquisition of Shares in Max New York Life Insurance by Axis Bank. Journal of Business and Financial Affairs, 6(283), 2167-0234. https://doi.org/10.4172/2167-0234.1000283

Lo, L. K., Osman, M., Ramayah, T., \& Rahim, M. (2010). The impact of service quality on customer loyalty: A study of banks in Penang, Malaysia. International Journal of Marketing Studies, 2(2), 57-66. https://doi.org/10.5539/ijms.v2n2p57

Malik, M. (2014). Bancassurance: Boon to Insurance Development. American International Journal of Research in Humanities, Arts and Social Sciences, 7(2), 155-159.

Markovic, S., Iglesias, O., Singh, J. J., \& Sierra, V. (2015). How does the perceived ethicality of corporate services brands influence loyalty and positive word-of-mouth? Analyzing the roles of empathy, affective commitment, and perceived quality. Journal of Business Ethics, 148(4), 721-740. https://doi.org/10.1007/s10551-015-2985-6 
McColl-Kennedy, J., \& Schneider, U. (2000). Measuring customer satisfaction: why, what and how. Total Quality Management, 11(7), 1-14. https://doi.org/10.1080/09544120050135434

Meneses, R. W., \& Larkin, M. (2012). Edith stein and the contemporary psychological study of empathy. Journal of Phenomenological Psychology, 143(2), 151- 184. https://doi.org/10.1163/15691624-12341234

Min. S., \& Khoon, C. C. (2013). Demographic factors in the evaluation of service quality in higher education: International Students' Perspective. International Reviell' of Management and Business Research, 2(4), 994-1010.

Moore, B. S. (1990). The Origins and Development of Empathy. Motivation and Emotion,14(2), 75-80.https://doi.org/10.1007/bf00991636

Neelamegan, R., \& Veni, K. (2009). Bancassurance - An Emerging Trend in Indian Service Sector, Indian Journal of Marketing, 39(10), 50-54.

Nunnaly, J. (1978). Psychometric Theory. New York:McGrow hill.

Nupur (2010). E-Banking and Customer Satisfaction in Bangladesh: An Analysis. International Review of Business Research Papers, 6(4), 145-156.

Nyadzayo, M. W., \& Khajehzadeh, S. (2016). The antecedents of customer loyalty: A moderated mediation model of customer relationship management quality and brand image.Journal of Retailing and Consumer Services, 30, 262-270. https://doi.org/10.1016/j.jretconser.2016.02.002

Parasuraman, A., Berry, L. L., \& Zeithaml, V. A. (1991). Refinement and reassessment of the SERVQUAL scale. Journal of retailing, 67(4), 420.

Parasuramam, A., Zeithaml, V. A., \& Berry, L. L. (1985). 17. Mohammad, AAS and SYM Alhamadani, 2011. A conceptual model of service quality and its Service quality perspectives and Customer implications for future research. Journal of Marketing, satisfaction in commercial banks working in Jordan, 49, 41-50.

Parasuraman, A., Zeithaml, V. A., \& Berry, L. L. (1988). Servqual: A multiple-item scale for measuring consumer perc. Journal of retailing, 64(1), 12.

Pettijohn, C. E., Linda S., Pettijohn, A. J., \& Taylor Bruce, D. K. (2011). Adaptive Selling and Sales Performance: An Empirical Examination. The Journal of Applied Business Research, 16(1), 91-111.https://doi.org/10.19030/jabr.v16i1.2031

Pilling, B. K., \& Sevo E. (1994). An Empirical Examination of the Impact of Salesperson Empathy and Professionalism and Merchandise Scalability on Retail Buyers' Evaluations. Journal of Personal Selling and Sales Management, 14(1), 45-58. 
Rajalakshmi, M. (2016). Studyon Customer Service Qualityof Commercial Banks inChennai City.International Conference on "Innovative Management Practices" Organize by SVCET, Virudhunagar.

Raju, S., \& Murugeshwaran, K. (2017). Suitabilityof Life Insurance Productsfor Different Risk Groups in India. International Journal of Marketing \& Financial Management, 5(3), 1120.

Ramez, W. S. (2011). Customers' socio-economic characteristics and the perception of service quality of Bahrain"s commercial banks. International Journal of Business and Management, 6(8), 113-126. https://doi.org/10.5539/ijbm.v6n10p113

RBI. (2015). RBI circular, available online at https://rbidocs.rbi. org.in /rdocs/notification/PDFs/IBROKIN150115.pdf

Redmond, M. V. (1989). The Functions of Empathy (Decentring) in Human Relations.Human Relations, 42(7), 593-605. https://doi.org/10.1177/001872678904200703

Rijwani, P., Patel, R., \& Patel, N. (2017). Service quality and customer satisfaction: Study of Indian banks using SERVQUAL. International Journal of Economic Research, 14(18), 199-211.

Roy, S., Singh, R., \& Singh, R. H. (2017). Impact of Financial Awareness on Financial Inclusion of Members of Self-Help Groups: A Study in Tripura.Asian Journal of Research in Banking and Finance, 7(8), 39-59. https://doi.org/10.5958/22497323.2017.00091.8

Rychlak, J. F. (1973). Introduction to Personality and Psychotherapy: A Theory Construction Approach. Boston: Houghton Mifflin

Safakli, 0. (2007). Credit risk assessment forthe banking sector ofNorthernCyprus. Journal of Yasar University, 615-30.

Santhiyavalli, G. (2011). Customer's perception of service quality of State Bank of India-A Factor Analysis. International Journal of Management \& Business Studies, 1(3), 78-84

Sasikala, D. (2013). Impact of demographics on service quality, customer satisfaction and loyalty in the Indian banking in Vellore district. Asia Pacific Journal of Marketing \& Management Review, 2(6), 102-116.

Schneider, B., \& Schechter, D. (1991). Development of a personnel selection system for service jobs. Service quality: Multidisciplinary and multinational perspectives, 217-236.

Shanka, M. (2012). Bank Service Quality, Customer Satisfaction and Loyalty in Ethiopian Banking Sector. Journal of Business Administration and Management Sciences Research, 1(1), 001-009. 
Sharma, V. C., Dhaundiyal, N. K., \& Srivastava, S. K. (2012). Customers' awareness towards banking services: a study of urban areas of Uttrakhand. South Asian Journal of Marketing and Management Research, 2(7), 63-75.

Siddiqi, K. O. (2011). Interrelationships between service quality attributes, customer satisfaction and customer loyalty in the retail banking sector in Bangladesh. International Journal of Business and Management, 6(3), 12-36.https://doi.org/10.5539/ijbm.v6n3p12

Siddiqui, S.A., \& Das, S. (2017). Life insurance, challenges and opportunities in Rural India. International Journal of advanced Research, 567874.https://doi.org/10.21474/ijar01/5130

Singh, R., \& Bhowal, A. (2009). Equity Investment Behaviour of Employees: A Study of Volume Dimension. Banijya, 2(1), 16-25.

Singh, R., \& Kar, H. (2011). Do the Highly Educated Subscribers Aware of it? New Pension Scheme in India. SIBACA Management Review, 1(1), 8-16.

Singh, R. (2012). Risk Perception of Investors in Initial Public Offer of Shares: A Psychometric Study. Asia-Pacific Journal of Risk and Insurance, 6(2), 115.https://doi.org/10.1515/2153-3792.1131

Singh, R., \& Bhattacharjee, D. (2010a). Equity Investment Decisions: Are Demographic Variables Really Significant? Paradigm-An IMT Journal, 14(1), 711.https://doi.org/10.1177/0971890720100103

Singh, R., \& Bhattacharjee, D. (2010b). Impact of Demographic Variables on Indirect Equity Investment: An Empirical Study. Indira Management Review, 4(1), 4-11

Singh, R., \& Bhowal, A. (2011). Development of marketing-driven measure of risk perception. The Journal of Risk Finance, 12(2), 140-152. https://doi.org/10.1108/15265941111112857

Singh, R., \& Choudhury, M. (2017). Measuring Customers' Perception in Bancassurance channel using Psychometric scale, DLSU Business \& Economics Review, 26(2), 1-6.

Singh, R., Singh, M., Pandiya, B., \& Upadhayay, C. (2020). IT-Governance Framework Considering Service Quality and Information Security in Banks in India. International Journal of Human Capital and Information Technology Professionals, 11(1), 64-91. https://doi.org/10.4018/ijhcitp.2020010105

Singh, S., Sirohi, N. J., \& Chaudhary, K. (2014). Study of Customer Perception towards Service Quality of Life Insurance Companies in Delhi NCR Region, Global Journal of Management and Business Research: E Marketing, 14(7), 19-31. 
Siu, N., \& Cheung, J. (2001). A measure of retail service quality. Marketing Intelligence \& Planning, 19(2), 88-96. https://doi.org/10.1108/02634500110385327

Solomon, M. R., Carol, F. S., John, A. C., \& Evelyn, G. G. (1985). A Role Theory Perspective on Dyadic Interactions: The Service Encounter. Journal of Marketing, 49(4), 99-111. https://doi.org/10.2307/1251180

Surprenant, C. F., \& Michael R. S. (1987). Predictability and Personalization in the Service Encounter, Journal of Marketing, 51(2), 86-96.https://doi.org/10.2307/1251131

Tagra, P., \& Dhiman, P. K. (2016). Insurance sector growth and performance: An analysis. Saudi Journal of Business and Management Studies, 1(3), 91-94.

Tsoukatos, E., \& Rand, G. K. (2006). Path analysis of perceived service quality, satisfaction and loyalty in Greek insurance. Managing Service Quality: An International Journal, 16(5), 501-519. https://doi.org/10.1108/09604520610686746

Urban, J. D., \& Pratt, D. (2000). Perception of banking services in the wake of banking mergers: An empirical study. Journal of Service Marketing, 14(2), 118- 31. https://doi.org/10.1108/08876040010320948

Van Dolen, W., Lemmink, J., De Ruyter, K., \& De Jong, A. (2002). Customer-sales employee encounters: a dyadic perspective. Journal of Retailing, 78(4), 265-279.

Van Iwaarden, J., van der Wiele, T., Ball, L., \& Millen, R. (2003). Applying SERVQUAL to Web sites: An exploratory study.International Journal of Quality and Reliability Management, 20(8), 919-935. https://doi.org/10.1108/02656710310493634

Venugopal, R. (2011). A Viable additional Channel- Bancassurance. IRDA Journal, 9(12), 3337.

Vera, J. \& Trujillo, A. (2017). Searching most influential variables to brand loyalty measurements: An exploratory study.Contaduría Y Administración, 62(2), 600-624. https://doi.org/10.1016/j.cya.2016.04.007

Vikas, G. (2011). Service Quality Perceptions of Customers about Insurance Companies: An Empirical Study, Indian Journal of Marketing, 41(3), 8-20.

Vimala, B., Alamelu, K. (2018). Insurance Penetration and Insurance Density in India, International Journal of Research and Analytical Review, 5(4), 229-232.

Viswanadham, P. (2005). Bancassurance in India: An Alternative Channel of Insurance Distribution. Indian Journal of Marketing, 35(11), 15- 19.

Weitz, B. A. (1981). Effectiveness in Sales Interactions: A Contingency Framework. Journal of Marketing, 45(1), 85-103.https://doi.org/10.2307/1251723 
Weitz, B. A. (1978). Relationship Between Salesperson Performance and Understanding of Customer Decision Making. Journal of Marketing Research, 14(4), 501516.https://doi.org/10.2307/3150621

Wieseke, J., Geigenmüller, A., \& Kraus, F. (2012). On the role of empathy in customeremployee interactions. Journal of Service Research, 15(3), 316-331. https://doi.org/10.1177/1094670512439743

Zaim, H., Bayyurt, N., \& Zaim, S. (2013). Service quality and determinants of customer satisfaction in hospitals: Turkish experience. The International Business \& Economics Research Journal, 9(5), 51-58.https://doi.org/10.19030/iber.v9i5.8145

Zeithaml, V.A., Berry, L. L., \& Parasuraman, A. (1996). The behavioural consequences of service quality. Journal of Marketing Management, 60(2), 31-46.

\section{Copyrights}

Copyright for this article is retained by the author(s), with first publication rights granted to the journal. This is an open-access article distributed under the terms and conditions of the Creative Commons Attribution license (http://creativecommons.org/licenses/by/4.0/) 